Imágenes intensas, ahora. Una lectura precipitada contra las mecánicas del desencantamiento Lucas Morgan Disalvo

Arkadin (N. ${ }^{\circ} 8$ ), e005, agosto 2019. ISSN 2525-085X

https://doi.org/10.24215/2525085Xe005

http://papelcosido.fba.unlp.edu.ar/ojs/index.php/arkadin

Facultad de Bellas Artes. Universidad Nacional de La Plata

La Plata. Buenos Aires. Argentina

\title{
IMÁGENES \\ INTENSAS, AHORA \\ Una lectura precipitada contra las mecánicas del desencantamiento
}

\author{
Intense Images, Now \\ A precipitated Reading Against the Mechanics of Disenchantment
}

\author{
LUCAS MORGAN DISALVO \\ z_ztardust@yahoo.com.ar \\ Facultad de Bellas Artes. Universidad Nacional de La Plata. Argentina
}

Recibido 17/3/2019 | Aceptado 12/6/2019

\section{RESUMEN}

Me interesa desarmar críticamente el tipo de artefacto político y estético que Salles construye en el film No Intenso Agora (En El Intenso Ahora, 2017) a partir del trabajo de archivo, en donde se pone en juego tanto una operación de clausura melancólica del evento como una operación de distanciamiento o desintensificación de las imágenes de los procesos políticos. La apuesta final es pensar otro tipo de acercamiento al archivo histórico desde una perspectiva de reencantamiento, en donde la organización de las imágenes obedezca menos a un principio nostálgico-desencantado sobre la historia que a una lógica de resonancias y reactivaciones capaces de hacer justicia a todas las intensidades que un presente contiene.

\section{PALABRAS CLAVE}

Film ensayo; imagen; política; historia; utopía

\section{ABSTRACT}

I am interested in disassembling, in a critical way, the political and aesthetic artifact that Salles creates in No Intenso Agora (In the Intense Now, 2017) from the archive work, in which an operation of a melancholic closing of the event as well an operation of distancing and deintensification of images of political processes are put into play. The final objective is to think about a different type of approach to the historical archive from a reenchantment perspective, in which the organization of the images complies less with a nostalgic-disenchanted principle on history than a logic of resonances and reactivations capable of doing justice to all levels of intensity that any present time carries.

\section{KEYWORDS}

Essay film; image; politics; history; utopia 
La historia no solo se compone de documentos y de imágenes. Es, por fundamento propio, una imagen en sí. La revuelta social en Francia en 1968, las protestas en Praga ese mismo año, un momento álgido de la vida personal, son todas ellas experiencias sensibles que delimitan marcos de posibilidad, modulan una capacidad de sentir, de pensar y de habitar un determinado tiempo. Pensar las relaciones complejas entre historia y archivo tiene que ver con honrar esta premisa [Figura 1].

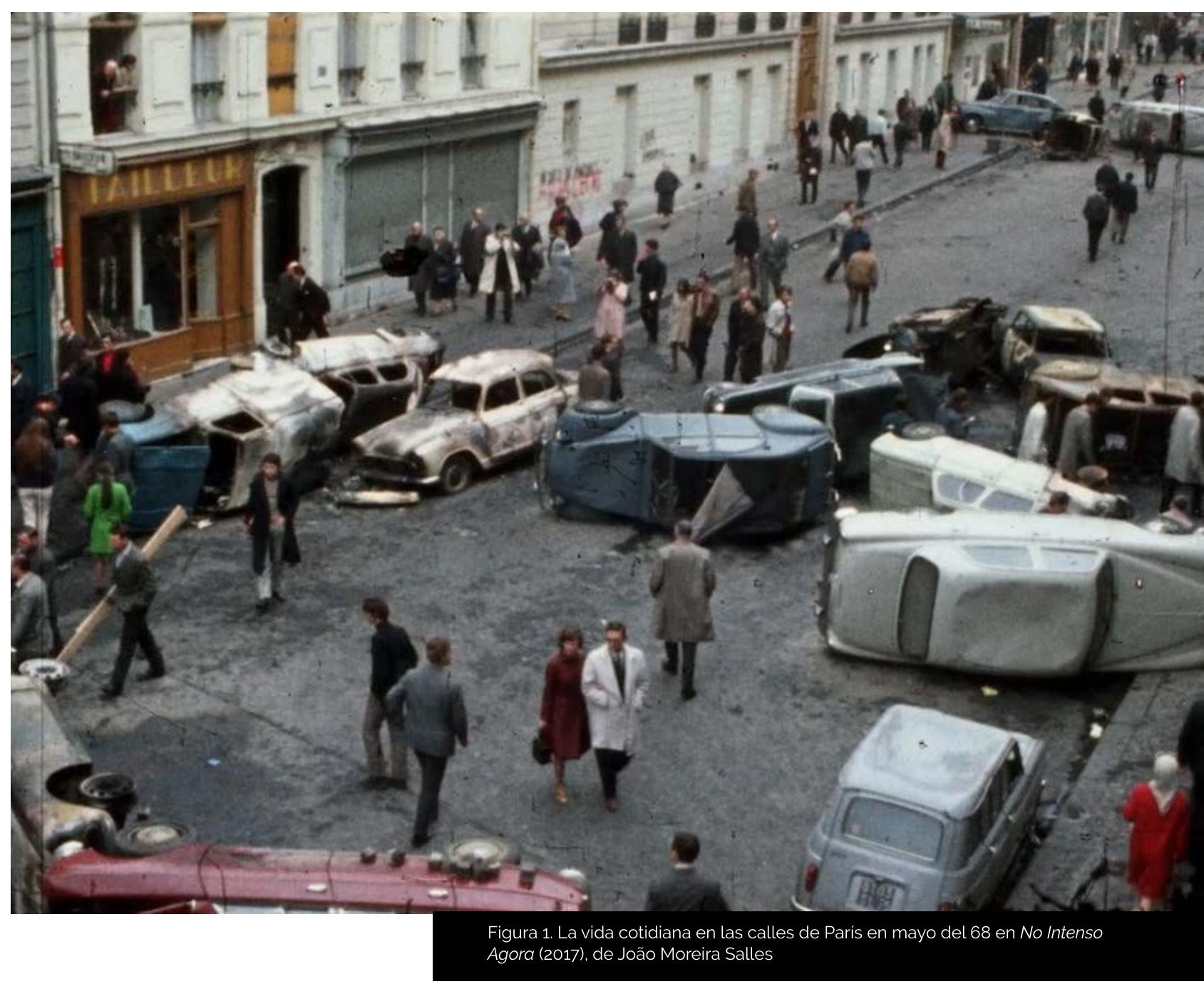

No Intenso Agora (En El Intenso Ahora, 2017) es un film de ensayo dirigido por el documentalista brasilero João Moreira Salles en el que se revisa la imagen-acontecimiento de la utopía política y sensible de los años sesenta en clave póstuma y desencantada. Parte del atractivo más inmediato de No Intenso Agora tiene que ver con la disposición exuberante de un gran trabajo de archivo sobre una década tumultuosa que goza de una poderosa sobrevida sentimental y política en nuestros imaginarios colectivos. Desfilan ante nuestros ojos registros poco conocidos o presentados con una nitidez vibrante que imprimen a las imágenes una fuerza emocional distinta de los repertorios formales con los que suele figurarse dicho período. Encontramos imágenes de lucha en movimiento y a color, por encima y desde adentro de las multitudes en las calles, apreciamos cada detalle en 
las hileras de brazos cruzados que avanzan. Más allá de la multiplicación de documentos, Salles ha comentado en numerosas oportunidades que no está interesado en hacer ninguna reposición histórica de los procesos políticos retratados en el film, sino más bien en poder ensayar una reflexión sentida sobre las pasiones, el problema del paso del tiempo y el impasse nostálgico en la vida de las personas. En palabras del director:

La pasión, que puede ser política, estética, sexual o amorosa, es estar enteramente en el momento, en el instante. Cuando pasa se pierde algo muy fuerte, una sensación de completud. ¿Cómo se hace para dar sentido al momento que no es más el momento de la vida apasionada? (Vespa, 2017, s. p.).

En ese sentido, a pesar de una procesión efervescente de fotografías, películas de colectivos militantes de la época, radiotransmisiones, entrevistas televisivas, lectura de documentos y films amateurs, no hay intensidad desde el ahora en el que Salles está observando todas aquellas imágenes, sino que la intervención editorial del presente se demora melancólica sobre el pasado como una reflexión aplacada, desaturada de pasión. La mirada crítica con la que se revisa la historia ya no tiene que ver con la voluntad fervorosa, amparada en la urgencia, la necesidad y el deseo, de actuar sobre una condición que despotencia, sino que emerge más bien como la decantación abatida de quien arriesgó demasiado en esas premisas irresponsables y que ahora recicla su propia fuente de fascinación en su propia posición desangelada.

De esta manera, el film elabora una lectura retrospectiva de distintos procesos históricos que surcaron la década de los sesenta, asimilándolo a la experiencia biográfica de una pasión extinta, una infatuación de juventud, una alegría vital que ya no volverá más. «Después de la revolución, la resaca».' Epígrafes en esta térmica acompañaron el estreno y la promoción de No Intenso Agora que revisita un tropo romántico-existencial sobre Mayo del 68 que nos es bastante familiar hasta la fecha: la narración acerca del esplendor y el final de un sueño colectivo, el pasaje desgraciado de un paraíso abierto donde todo era posible a una posteridad adulta irremediablemente extraviada en la contemplación de su propia desesperación actual. A esta altura, podría decirse que éste es un lugar común que sobrevuela gran parte de los gestos retrospectivos y conmemorativos contemporáneos, todos ellos encabalgados en una suerte de un mediotono reflexivo, una reserva moderada con la que se aproximan en la actualidad muchos procesos políticos que, alguna vez, significaron algo. Mayo del 68 hoy: habiéndose cumplido cincuenta años del estallido, entre la responsabilidad intelectual del balance y la fiebre vertiginosa de la memorabilia, al calor de tanta efeméride, dossier temático, exposición, revisión, conversión ideológica, actos oficiales e intercambios expertos entre protagonistas, allegadxs, enemigxs y herederxs históricxs, podemos corroborar que éste ha sido convertido en una suerte de legado político monumental acerca de la imposibilidad de la transformación histórica. Visto de esta manera, Mayo del 68 oficia como recordatorio de que el mundo ha cambiado cuando comprueba que sigue igual, sin que esto sea el corazón de ninguna paradoja.

\section{CIERREN LA HISTORIA, QUEREMOS CONMEMORAR}

Siguiendo a Enzo Traverso (2018), los efectos de la monumentalización introduce un antagonismo complejo entre memoria e historia, al ser fruto de una aspiración del poder que apunta tanto a la consagración del pasado histórico como objeto del recuerdo - como cuando Jacques Derrida (1997) observa que archivar en ese sentido es meter en prensa, «hacer historia»- así como al cierre sobre lo que se mueve, la clausura del proceso histórico. De esta manera, el monumento funciona como un artefacto inapelable de conservación del pasado, al que se le concede la potestad trascendental de

1 Ese fue el título paradigmático con el cual la plataforma brasilera Trip TV entrevistó a Salles en ocasión del lanzamiento de No Intenso Agora. 
salirse por fuera de la historia para poder capitalizar una última palabra sobre esta; los monumentos son, como señala Nicolas Whybrow (2005), «representaciones que desean que solo una cosa sea pensada o sentida de ellas» (p. 107).

Estos artefactos conmemorativos implican formas de destrucción de las políticas utópicas a través de su cosificación y privatización dentro de un mundo reificado: aquella memoria que antes era incorporada a las luchas históricas, hoy pasa a ser un bien de culto para nostálgicxs (Traverso, 2018). ${ }^{2}$ ¿En qué consiste parte de este fenómeno de monumentalización de Mayo del 68? En su reducción unívoca a una imagen dolosa omnipresente: el confinamiento al recuerdo, el lamento sobre un cambio de época, la añoranza por una primavera histórica extraviada. La eficacia de este tropo reside en la amarga estabilidad que provee la revisión desmitificadora en clave de coda, al pretender hacer entrar en razón al fantasma desquiciado de la historia que no deja de insistir esto aún no ha terminado. En efecto, tanto la idealización utópica del Mayo Francés como su disección desencantada colaboran en un atroz dispositivo de monumentalización de los procesos históricos: así como el lugar generalizado del romanticismo sesentayochista consagra aquellos años como el ejemplo auténtico de una intensidad desatada, irrepetible e irrecuperable, existe igualmente una profunda cualidad romántica dentro de la misma desazón melancólica con la que se vuelva a estas imágenes en el presente, una mezcla templada de resignación, arrepentimiento y rectificación que ayuda a que las políticas pragmáticas de lo posible puedan dialogar en buenos términos con la propia miseria: ${ }^{3}$ «Si la primavera del 68 fue de utopía, el verano será del orden y de derecha» (Salles, 2017, 01:12:01). Leída desde el presente, la imagen de mayo en 1968 es revisada como un monumento sobre la propia condición melancólica e inevitabilidad de la historia, en el que la intensidad del pasado adopta para siempre la frecuencia de una nausea ininterrumpida en el presente. Aún antes de Francis Fukuyama y del fin de la historia, un sentido más coloquial de determinación histórica se esconde en aquella otra imagen que se le atribuyó míticamente a Winston Churchill y que se popularizó como una suerte de moraleja existencial amarga después de la posguerra: «Si a los veinte años no se es de izquierda, no se tiene corazón; si a los 40 no se es de derecha, no se tiene cerebro».

\section{BELLO LO QUE SE HA PERDIDO, FELIZ LO QUE HA TERMINADO}

Si bien la premisa crítica que construye vasos comunicantes entre las dimensiones macropolíticas y biográficas forma parte de la operatoria de una película que continuamente intercala «grandes imágenes oficiales» con registros más íntimos a fines de complejizar qué es lo que sentimos en primera instancia como historia, no es lo personal lo que No Intenso Agora termina por inscribir políticamente en el mundo, sino que por el contrario, es el mundo de lo político aquello que se vuelve introyecta y se vuelve personal, confinado al receptáculo de la emoción privada. Este giro psicologizante del tiempo histórico podría pensarse como una de las formas en las que actúa aquella matriz denominada por Elizabeth Freeman (2010) como crono-normatividad: «Un modo de implantación, una técnica a través de las cuales las fuerzas institucionales se asemejan a hechos somáticos» (p. 3). La crono-normatividad concibe el enfoque temporal con el que se piensa a los procesos políticos y biográficos a partir de un encuadre lineal que la autora considera «novelístico», una estructura narrativa congruente «centrado en eventos, orientado en propósitos, intencional, culminando en epifanías o transformaciones

\footnotetext{
2 Mark Fisher (2018) denunciará el fenómeno de la nostalgia contemporánea como la extensión de monumentalización informal del pasado, una suerte de reticencia sostenida a la experiencia sentida del presente histórico. Por su parte, Elizabeth Freeman (2010) nos recuerda que, para Jacques Derrida, la nostalgia es una forma de retorno aceptable y domesticado del pasado, una vez que se ha asegurado como certeza la condición de que «la revuelta, aquello que inicialmente inspiró el levantamiento, la indignación, la insurrección, el momento revolucionario ya no vuelva más» (p. 14).

3 Término forjado inicialmente por André Breton y luego expandido por el Grupo Surrealista de Chicago en 1968, en particular por lxs poetas militantes Penelope y Franklin Rosemont, la noción de miserabilismo denuncia «un sistema que produce miseria y luego la racionaliza perpetuando la idea de que dicha miseria conforma la única realidad posible» (Sakolsky, 2013, p. 129).
} 
mayores» (Freeman, 2010, p. 5) en la que podríamos agregar, también existe un lugar y un momento para las lógicas recesivas del tiempo, el desgaste inevitable de aquellos puntos altos.

Tanto la prosperidad como la melancolía forman parte de una secuencia entrópica con la que se entiende el paso del tiempo en las sociedades occidentales: en un extremo, la juventud queda cristalizada como la imagen de un impulso vital sin pausa, acción deprivada de conciencia histórica y comprometida en un estado de presente continuo, en otro, aparece una imagen de madurez proverbial amortiguando todo ese movimiento con un temple escéptico, inercial, secretamente capturado en su irremediable nostalgia sobre otros tiempos más felices. En esta operación, el pasado queda reducido a un veredicto sobre la felicidad y la intensidad, mientras que el presente es tan solo aquel lugar donde la quietud constante de la melancolía estaciona. «Mayo del 68 ya no está aquí», dirá la película en varios momentos. Su manera de sostener este argumento es demorarse exclusivamente en la juventud álgida de sus protagonistas retratadxs, enalteciendo la embestida irreverente de la guardia joven como un punto incandescente de belleza sobre la que luego se desatará la masacre del tiempo. [Figura 2].

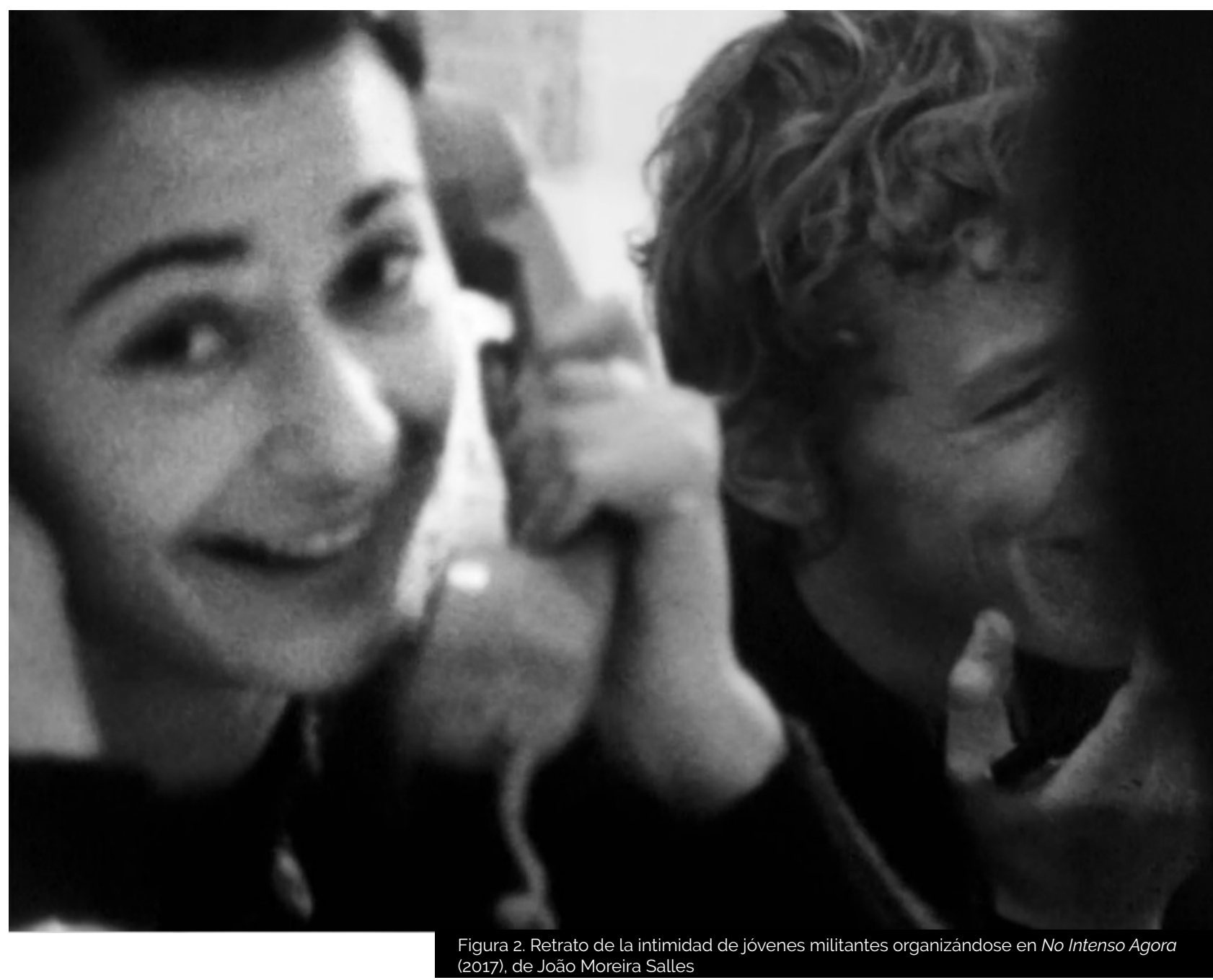


Hablemos de algunas imágenes de distintos momentos de No Intenso Agora. Observamos un film casero que describe una boda de personas desconocidas en Checoslovaquia de 1968, que se abrazan, bailan y festejan sonrientes; la voz de Salles indica «es verano de 1968 y esas personas están felices» (Salles, 2017, 00:01:25). Vemos a un grupo de estudiantes reunidos, una joven conversa por teléfono con una madre de uno de los estudiantes en lucha, preocupada por su hijo que no regresa a casa desde hace una semana por lo menos. La película señala que ese momento será el punto máximo en la vida de los jóvenes, demasiado ocupadxs en la intensidad de su sensación, en la realidad de su energía. Sobre el correr de aquellas risas y complicidades, Salles diagnostica «difícilmente volverán a ser tan felices» (Salles, 2017, 00:34:17).

En otra parte del film, el autor repasa algunos de los primeros planos cerrados de Ce N'est Qu'un Debut (1968), del colectivo Arc, el primer film directamente salido de aquellos días de mayo. Sobre el pasar de distintas escrituras extáticas que escupen su rabia contra el fascismo de las instituciones universitarias, el director apunta una de las consignas claves de aquel entonces: «La felicidad es una idea nueva» (Salles, 2017, 00:12:43). De esta manera, podemos ver que Salles está proponiendo a la felicidad como una especie de clave sintagmática con la que hacer sentido de esas imágenes tan diferentes entre sí. En una entrevista (Vespa, 2017, s. p.), el director comenta que la idea del film surgió de una epifanía tras revisar el archivo familiar y encontrar imágenes de un viaje de su madre a China durante la época de la revolución cultural en octubre de 1966, un episodio que No Intenso Agora caracterizará como una vivencia de sublimidad absoluta de la que ella jamás pudo recuperarse:

Entonces la idea era entender por qué estaba tan feliz, tan ligada a ese momento. Por ese entonces, vivíamos en Francia. El golpe militar fue en 1964 y mi padre era ministro del gobierno depuesto. En 1968 estábamos en París, la influencia de los maoístas que mamá encontró durante la revolución cultural de 1966 fue muy grande en 1968. Leyendo las biografías encontré que los que vivieron en 1968 encontraron la misma sensación de totalidad y la pérdida de algo muy fuerte.

Sara Ahmed (2019) ha indagado en la manera en la que la imagen de felicidad, en tanto experiencia de plenitud sostenida, desinteresada por el tiempo, es el epicentro de muchos de los armazones teleológicos que estructuran el pensamiento occidental moderno: se vive para ser feliz, el sentido de la vida es ser feliz. La felicidad tiene una función prospectiva, funciona como promesa de un futuro anhelado que vendría a saldar las cuentas del presente. Dirá Ahmed (2019): «Junto con su naturaleza promisoria, la felicidad guarda relación con el modo en el que algunas cosas se convierten en bienes aún antes de que tengamos la fortuna de encontrarnos con ellas» (p. 85). El artefacto melancólico de No Intenso Agora hace de la felicidad un bien que es consagrado retrospectivamente, en el interior de muchas de las imágenes que componen el film. En contacto con una extraña e intensa fuerza de agitación que mira desde las imágenes (una que no es esencial ni necesariamente feliz), la melancolía advierte en ellas el aura de lo irrepetible y la condición de lo irrecuperable.

\section{LA HISTORIA ES UNA CANCIÓN TRISTE}

En «Melancolía de Izquierda», un breve y feroz reseña de 1931 sobre la obra de Erich Kästner, Walter Benjamin nos introduce a la idea de un tipo de estructura sentimental muy difundida como sofisticada mercancía para cierta clase intelectual de su época. En relación con las imágenes sórdidas que componen el repertorio emocional de la Nueva Objetividad, el filósofo alemán se preguntará:

[...] ¿Qué encuentra la «elite intelectual» al hacer el inventario de sus sentimientos? ¿Acaso estos mismos sentimientos? Ellos hace tiempo fueron malvendidos. Restan solo los lugares vacíos donde otrora, en polvorientos corazones de terciopelo, estuvieron guardados los sentimientos: la naturaleza y el amor, el 
entusiasmo y la humanidad. Ahora uno acaricia distraídamente la forma vacía. Una ironía autoconvencida cree que esas formas vacías tienen más valor que las propias cosas, ostentando su pobreza como un lujo y transformando en fiesta ese monótono vacío. Pues lo «nuevo» de esa «objetividad» es que se vanagloria tanto de los vestigios de antiguos bienes espirituales cuanto el burgués de sus bienes materiales. Nunca nadie se acomodó tan a su voluntad en una situación tan incómoda (Benjamin, 1931, s. p.).

De esta manera, la melancolía de izquierda es caracterizada como una disposición reaccionaria dentro de la propia subjetividad crítica, que la vuelve afecta a ensimismarse en el regocijo de la propia miseria e insatisfacción, al punto de renunciar a todo horizonte prospectivo y perderse en la romantización sobre su propia cancelación. Para Benjamin (1931), el melancólico de izquierda prefiere afirmarse con soberbia en la regresión elitista y el fatalismo de cada día, renunciando así «a la capacidad de sentir repugnancia» (s. p.) porque ha encontrado en esta introspección miserable una suerte de iluminación privada de elevado valor poético. Es así como el autor denunciará que aquel realismo sórdido no puede encontrar otro registro que no sea llorar la propia tristeza y culpa, no es otra cosa que un gesto funcional que reconcilia a un individuo consigo mismo y lo lleva a cortejar poéticamente con la coyuntura, acostumbrándolo a pasar por encima de cadáveres, convenciéndolo de que esta existencia diaria viciada de imposibilidad no es otra cosa que una enriquecedora experiencia lírica.

Una de las primeras definiciones de melancolía como una especie de condensado orgánico indecible que crece apoderándose del cuerpo (Traverso, 2018) regresa en obras que trabajan la melancolía como una suerte de duración espesa y expansiva que absorbe a las imágenes, volviéndolas un remanso apacible del color de una tonalidad indiferenciable. En relación proporcional con la capacidad extensiva de la melancolía de No Intenso Agora sobre las imágenes, el foco sobre la historia de 1968 se irá cerrando. La cámara lenta abunda en la película para seleccionar gestos sobre otros, rostros sobre otros, como una forma de indagación sobre el secreto emocional que desborda ciertos cuerpos. La música del film es prácticamente posterior, no escuchamos sonidos de aquella época. La ausencia de voces de quienes participaron de aquellos eventos es algo notable, vemos algunos (mismos) rostros pero las perspectivas de dichxs sujetxs no están ahí, sino a modo de vagas y esporádicas citas.

La acción que se muestra en relación a aquellos años en los que «cada segundo tenía la espesura de la eternidad» (Salles, 2017, 00:21:40) retratada como un parpadeo de algo que se enciende y se apaga, un incidente casi accidental que termina siendo devorado por su caprichosa falta de arraigo en las bases concretas de la sociedad: concluirá Salles «era como si todo fuese posible, menos la toma del poder» (Salles, 2017, 00:52:32). El problema de reducir Mayo del 68 a un instante de singularidad excepcional es aislarlo de todo un mapa complejo de movimientos, anteriores, posteriores, paralelos, resonancias históricas. Y allí empiezan las objeciones a esta intensidad idealizada que el film mismo está proponiendo. El documental se despachará convenientemente con la crítica de que en París el movimiento fue menos profuso que en otras partes, señalando que los registros históricos oficiales, los líderes siempre eran hombres blancos y que en esas imágenes, las mujeres escuchan más de lo que hablan. En otro momento, denuncia que, en esas mismas representaciones, las personas negras siempre ocuparán los extremos del cuadro, en un lugar secundario. Sin embargo, aquellxs sujetos considerados problemáticxs o exceptuadxs por la narración política tradicional de aquellos años, que bien sostuvieron discursos críticos y que disputaron poder en sus coyunturas, no tienen espacio de expresión en un film, que de alguna manera continua capturado por esa misma construcción historiográfica que en teoría se estaría repudiando: pasan las imágenes y solo vemos hablar en ellas a un puñado particularizado de hombres blancos, parisinos, jóvenes estudiantes que han pasado a la historia como referentes famosos de Mayo del 68. 
En diálogo con el mundo social, ninguna imagen es inocente y, sin embargo, hay imágenes que, efectivamente, el film no dejará de pensar poéticamente como enclaves de inocencia. Estas son las imágenes de la boda, del álbum familiar, del reportaje turístico de su madre, que operan como objetos felices (Ahmed, 2019) porque en ellas Salles verá una manifestación de una inocencia prediscursiva fundida en el tejido mismo del presente sin tener conciencia del tiempo que la acecha. Los registros en $16 \mathrm{~mm}$ del viaje a China introducen cíclicamente una pausa sensible en el film, donde la mirada occidental se concibe a sí misma como una mirada sin tiempo, que pasea y que produce postales donde las referencias coyunturales se sienten menos arraigadas y la historia solo puede afectar recreativamente a los sentidos, presente como una reliquia cultural, un decorado exótico para el spleen turístico que se regodea en el encuentro casual con enseñanzas, templos y monumentos ancestrales. Observará el director sobre las coloridas imágenes de un grupo de niñxs ensayando una coreografía oficial:

Al ver un grupo de niños ensayando un ballet revolucionario, no hizo alusión ni a la trama ni a la propaganda. Prefirió describir las manos, a las que consideró «las más lindas de la Tierra». Vio la belleza en la finura de los dedos y en su fácil movilidad, e identificó la inspiración en los gestos de los niños, no en alguna coreografía militar, sino en la pose de las figuras de la antigua porcelana china (Salles, 2017, 00:25:32).

Estos momentos parecieran conformar un continuum estético suspendido, idilios evanescentes en los que, como dirá Salles, «la belleza vive aparte, lejos del drama de los hombres» (Salles, 2017, 00:51:54). La voz over, a pesar de introducir registros del orden de lo cancelado —«mi madre jamás volverá a ser tan feliz» (Salles, 2017)—, construirá por la vía del tono sentimental, un ensalzamiento estético de lo que estamos viendo. La historia de las relaciones de poder entre Occidente y Oriente queda escamoteada por este principio colonial de ensoñación occidental sobre la experiencia política e histórica oriental [Figura 3].

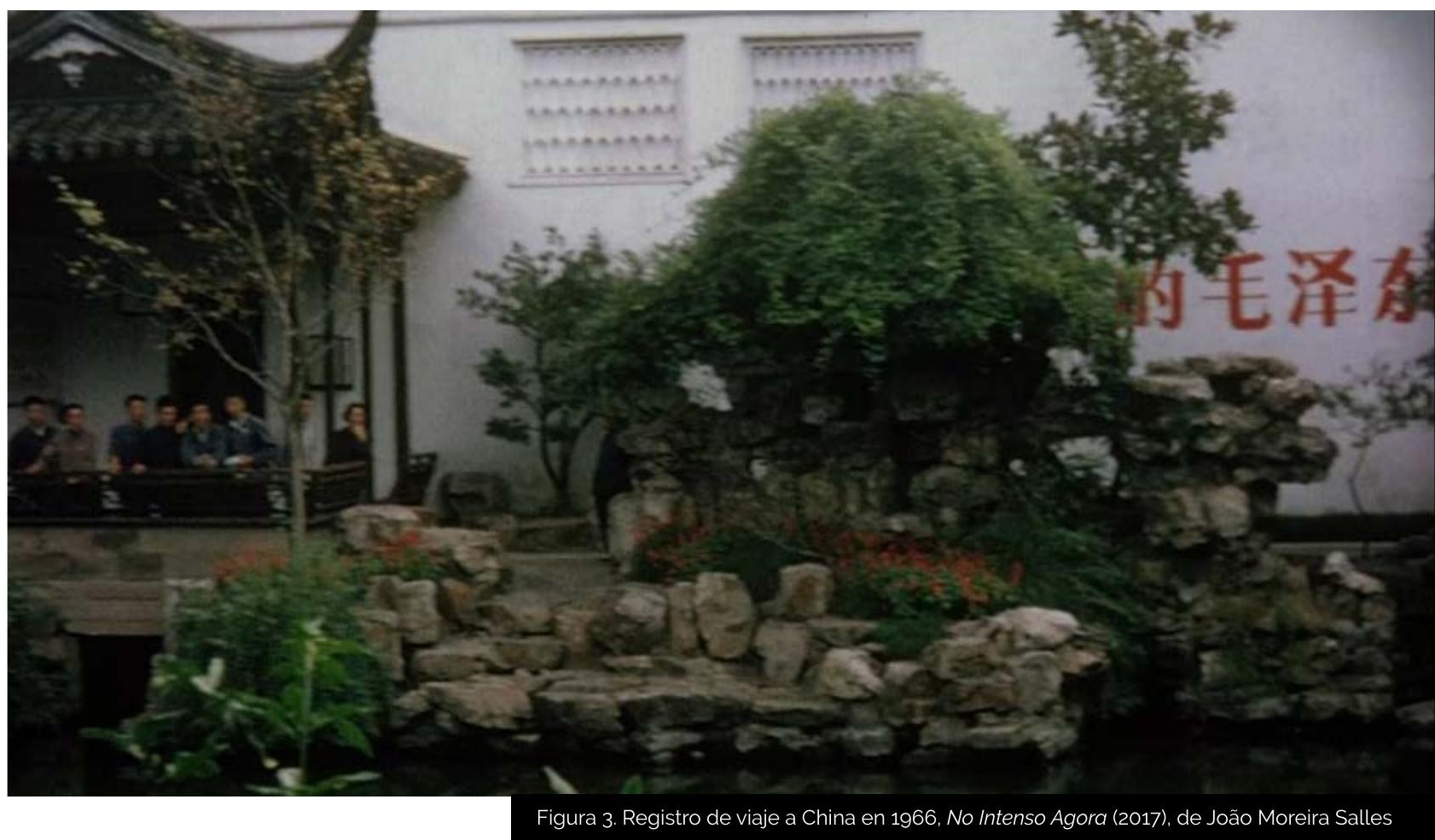




\section{EL CARISMA DEL DESENCANTAMIENTO}

Esta idealización nostálgica que convierte a la historia en un juguete de contemplación, se articula con elementos que podríamos señalar como desencantadores: el detenimiento del fotograma, la pausa, el recorte de la imagen a través del silencio de edición y el paso al comentario, un trabajo de disección analítica en la que imagen con fines argumentativos y demostrativos. Hay una insistencia en la operatoria del film que se repite, un mecanismo que aísla esas ciertas imágenes, volviéndolas unidades visuales de intensidad (un adoquín arrancado directamente de la calle y siendo arrojado a la policía, una joven obrera que desacredita la autoridad del patrón y de los dirigentes sindicales, un graffiti que denuncia a las instituciones universitarias como cómplices) para luego proceder a apagarlas. Son momentos en los que el film abre paso brevemente a una imagen fuerte y sugerente, dejando correr su poder de afectarnos, para luego pausarla, intervenirla en cámara lenta, apagar su sonido, destruir la iconocidad, controlar sus resonancias, crear distancia. La mayoría de las veces la inserción de este comentario va a decir que lo que estamos viendo no es lo que parece, que esto que tiene el poder de conmovernos y de atravesarnos la piel, que funciona como influencia en el sentido más literal del término, no es lo que creemos.

Es difícil no ver a No Intenso Agora como una película partida, cimentada sobre una división que me gustaría poder problematizar aquí: la ilusión, la esperanza y la alegría puesta del lado de las imágenes, su exuberancia, su profusión; el desencanto, la inteligencia y la sordidez, en el comentario en over del autor que organiza e interpreta el archivo. A lo largo del film, imagen y comentario over son puestas a jugar en una especie de campo permanente de oposiciones que de alguna manera afianza aquel reparto de relaciones de poder estáticas entre sujeto y objeto, materia sensible y pensamiento abstracto. Esta idea de pensamiento crítico prioriza la razón como instrumento desmitificante al servicio de lo real, despoblado de imágenes encantadoras y ficciones ardientes a quienes se deposita del lado de la falsa conciencia, la prestigitación y la ilusión. Existe un principio platónico atorado en el imaginario crítico occidental que postula que la única relación que el pensamiento puede llegar a tener con las imágenes es a través del acto vertical de la develación, aquel momento de conquista intelectual en donde toda superficie ilusoria, toda arquitectura ficcional es removida para dar paso a la verdad, relampagueando como una presencia angélica, total y absoluta. En este sentido, el escepticismo iconofóbico de esta crítica concibe esta potencia únicamente bajo los términos de una manipulación desleal que necesita ser desmentida.

En distintos momentos del film se pone en juego esta lógica desencantadora. Volvamos a la imagen de aquella cadena de personas pasándose el adoquín de mano en mano. Segundos antes, el director había mencionado que «debajo de los adoquines, la playa» (Salles, 2017, 01:51:26) había sido una de las consignas más famosas de Mayo del 68, porque era una de las que mejor sintetizaba sus promesas. Salles pone en movimiento esta consigna mostrándonos planos en las que la cámara va siguiendo el recorrido coordinado de esta piedra arrancada de la calle, mientras escuchamos la hipnótica cadencia del mar. Aquí, el comentario introduce un contraargumento revelador de aquello que vemos: la frase no surgió espontáneamente de la imaginación de un estudiante, sino que fue un producto calculado de un brainstorming trasnochado por parte de dos empleados de una agencia de publicidad. «No todo es lo que parece» (Salles, 2017, 01:53:41) sentencia la película con un goce innegable, evidencia de que Mayo del 68 en sí mismo termina siendo una de estas imágenes desleales, una prueba más del modo en el que se juega la invención verbal de la historia: lo que se ve en las imágenes, nunca estuvo allí verdaderamente. 


\section{VECTORES DE POSIBILIDAD: IIMÁGENES INTENSAS AHORA!}

Impugnar una imagen diciendo que se trata solo de una imagen es renunciar a las facultades operatorias de la misma, algo que sin duda alguna tuvieron en cuenta quienes participaron de la experiencia política y sensible de Mayo del 68. Georges Didi-Huberman (en Cortés y otros, 2010) remarca cómo, paradójicamente, Guy Debord acusaba de este desprecio rotundo a las imágenes, pero a la vez su pensamiento político era elaborado a través de la producción intensiva de fabulosos atlas de imágenes. Jacques Rancière (en Game, 2009), por su parte, señalará que no deja de haber un sentido de encantamiento en la destreza argumentativa prodigiosa de aquel sujeto que cuenta la verdad escondida detrás de las apariencias:

[...] queda, pues, finalmente, la autoridad de la voz que enuncia el poder del espectáculo. Esto es particularmente evidente al ver las películas de Debord ya que en ellas hay un desfile de imágenes indiferente en cierto sentido [...] y solo cuenta la voz que dice: «estás ante estas imágenes, mirando como un cretino, pues estas imágenes son como tu propia muerte». Esa voz que señala la separación, en cierto sentido la consagra: dice que todos estamos en las imágenes - así será siempre-, pero nunca nos saca en ellas. Queda un espectáculo que confirma la autoridad de la voz que dice: «siempre estarás dentro» (s. p.).

El comentario que estructura gran parte del artefacto de No Intenso Agora trabaja en un sentido similar: si bien las imágenes que expone no le pertenecen, ejerce un sentido de propiedad editorial al indicarnos cómo leerlas. El análisis relatado de un acontecimiento desarma una imagen y explica sus fundamentos originarios y sus intenciones verdaderas; quien se erige en autoridad encantadora termina siendo aquel artífice que devela lo que ni nosotrxs ni la cámara sabemos. Pero tal como sucede en un ejercicio de ilusionismo, la fascinación espectacular no se interrumpe porque alguien nos cuente el truco. En todo caso, aquella fascinación pasa a estar transferida al mago que «hace consciente», quien sabe y nos hace participar - parcialmente- de un saber que antes no se tenía. Pero en última instancia, el mago quien usa las imágenes para decirnos que éstas no deberían encantarnos, produce una extraña forma de encantamiento que no se cuenta como tal.

Uno de las momentos desencantadores más fuertes de No Intenso Agora es aquel que narra, al llegar el mes de junio en Francia, el final de la huelga general, a través del retorno a la fábrica de Wonder. Vemos a lxs trabajadorxs agolpadxs discutiendo en la puerta de la fábrica, una operaria llora de rabia e impotencia frente al anuncio oficial de los representantes sindicales, que intentan persuadirla de que la lucha no se ha perdido, de que «esto es solo una etapa» (Salles, 2017, 01:05:34) y que es imposible «conseguir todo a la primera» (Salles, 2017, 01:05:44). La imagen siguiente será un plano fijo y extendido en el que distintos trabajadorxs ingresan al edificio, casi una demostración pedagógica del poder disciplinador del capital. En un momento de esa misma imagen vemos a una mujer que sale en dirección contraria a todxs (xs demás, mascullando con asco: «Yo no voy a entrar, de hecho no tengo ganas» (Salles, 2017, 01:09:49). Es así como, a pesar de estos vectores de derrota, a pesar del propio film, hay todo el tiempo cosas que suceden y que nos suceden, justamente a partir de las mismas imágenes.

Probemos a poner en silencio aquel registro filmado de la piedra pasada de mano en mano, mientras retenemos las resonancias de la frase «debajo de los adoquines, la playa» (Salles, 2017, 01:51:26). Según la versión que Salles desmiente, esta consigna nace aparentemente de un descubrimiento literal: cuando algunxs manifestantes encontraron que podían servirse de aquellos adoquines que en la vida cotidiana formaban parte del suelo mismo sobre la cual la vida corría, y transformarlos en objetos de uso, hallaron una extraña forma de éxtasis. Las imágenes, al igual que los adoquines, deben usarse. Su capacidad de (re)encantarnos puede resonar con aquello que Walter Benjamin (1998) 
consideraba lo propio del empeño surrealista: «Se trata de ganar las fuerzas de la embriaguez para el servicio a la revolución» (p. 313).

Quisiera concluir este abordaje preguntándome hasta qué punto ese gesto de distancia escéptica (tan susceptible de glamourizarse como la imagen más carismática de la revuelta) que el film propone como toque de queda para la romantización del Mayo Francés- es capaz de detener verdaderamente lo que esas imágenes libres, sueltas, rehabitadas, resignificadas, reevocadas, son capaces de hacer en nosotrxs? ¿Y lo que nosotrxs podemos llegar a hacer con ellas? Me pregunto hasta qué punto estas operaciones de desencantamiento que el film de Salles pone en juego son totalmente capaces de desmentir la historia que tenemos desde el presente, una historia no necesariamente real en términos fácticos, sino y por encima de todas las cosas, una historia política y afectiva común, habitada, sentida, recuperada, resignificada y reactivada transversalmente. Asumir la complejidad de ciertos procesos políticos tan auratizados como Mayo del 68 no implica, solamente, reponer todo aquello que no se vio o no se supo de ese momento, sino hacerse cargo de la transversalidad histórica, de su carácter de dominio abierto para la invención colectiva, evitando la editorialización que privatiza la historia y cierra celosamente el margen que esas imágenes puedan ser usadas con nuevos y necesarios sentidos [Figura 4].

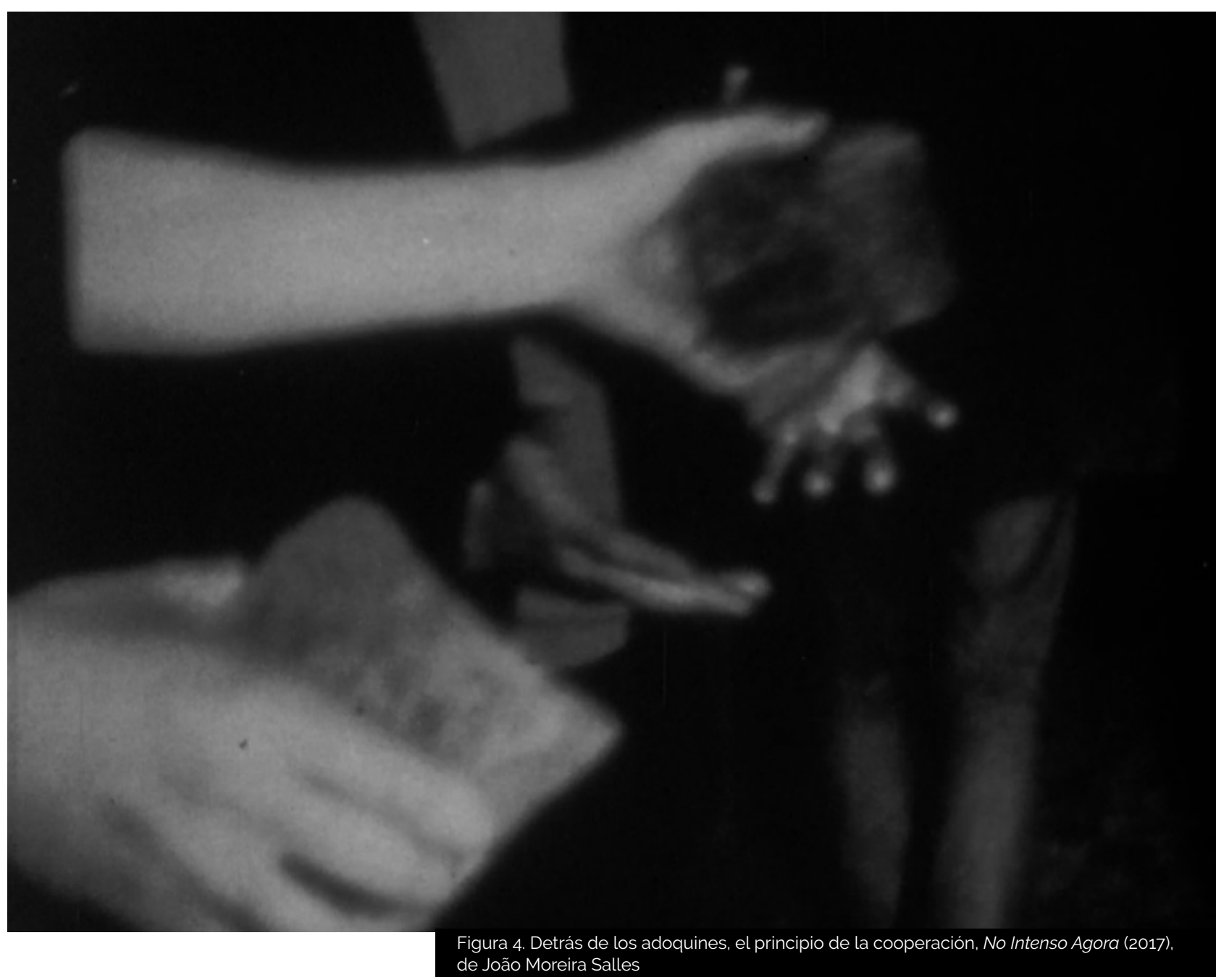


Érase una vez (o al menos, eso se dice) una consigna anónima escrita en las puertas de la facultad de Nanterre, durante los agitados días de Mayo del 68, anunciaba: «Exagerar, jésa es el arma!». Quisiera ver en esta frase del pasado una contraproposición sensible a la película de Salles, una sugerente invitación a pensar que, después de todo, las imágenes son de quienes las habitan.

\section{REFERENCIAS}

Ahmed, S. (2019). La Promesa de la Felicidad. Una Critica Cultural al Imperativo de la Alegria. Ciudad Autónoma de Buenos Aires, Argentina: Caja Negra.

Benjamin, W. (1931). Melancolia de izquierda. Sobre el nuevo libro de poemas de Erich Kästner ITrad García, L. I.]. Recuperado de https://www.academia.edu/7642464/Walter_Benjamin_1931_ Melancol\%C3\%ADa_de_izquierdas

Benjamin, W. (1998). El Surrealismo. En R. Tiedemann y H. Schweppenauser (Eds.). Walter Benjamin, Obras, libro II/vol. Madrid, España: Abada Editores.

Cortés, D.; Garcia, E.; Fernández Savater, A. (18 de diciembre de 2010). Las imágenes son un espacio de lucha. Público. Recuperado de https://blogs.publico.es/fueradelugar/183/las-imagenes-son-unespacio-de-lucha

Derrida, J. (1997). Mal de Archivo. Una Impresión Freudiana. Madrid, España: Trotta.

Fisher, M. (2018). Los Fantasmas de Mi Vida. Ciudad Autónoma de Buenos Aires, Argentina: Caja Negra

Freeman, E. (2010). Time Binds. Queer Temporalities, Queer Histories IEl Tiempo Nos Ata. Temporalidades Queer, Historias Queer]. Durham, Estados Unidos: Duke University Press.

Game, J. (2009). Critique de la critique du «spectacle» [Crítica de la crítica del «espectáculo»]. Revue internationale des livres et des idées, (12).

Sakolsky, R. (2013). Creating Anarchy [Creando Anarquia]. Ferndale, Estados Unidos: Fifth Estate Books. Salles, J. M. (Director). (2017). No Intenso Agora [Pelicula]. Brasil: Videofilmes Produçoes Artisticas Ltda.

Traverso, E. (2018). Melancolia de Izquierda. Marxismo, Historia, Memoria. Ciudad Autónoma de Buenos Aires, Argentina: Fondo de Cultura Económica.

Vespa, M. (22 de septiembre de 2017). Geometría de la Pérdida. La Agenda Revista. Recuperado de https://laagenda.buenosaires.gob.ar/post/165608177030/geometr\%C3\%ADa-de-La-p\%C3\%Agrdida

Whybrow, N. (2005). Street Scenes: Brecht, Benjamin and Berlin [Escenas de la Calle: Brecht, Benjamin y Berlin]. Bristol, Reino Unido: Intellect Books. 